\title{
Past and Future Sea Level Changes and Land Uplift in the Baltic Sea Seen by Geodetic Observations
}

\author{
M. Nordman, A. Peltola, M. Bilker-Koivula, and S. Lahtinen
}

\begin{abstract}
We have studied the land uplift and relative sea level changes in the Baltic Sea in northern Europe. To observe the past changes and land uplift, we have used continuous GNSS time series, campaign-wise absolute gravity measurements and continuous tide gauge time series. To predict the future, we have used probabilistic future scenarios tuned for the Baltic Sea. The area we are interested in is Kvarken archipelago in Finland and High Coast in Sweden. These areas form a UNESCO World Heritage Site, where the land uplift process and how it demonstrates itself are the main values. We provide here the latest numbers of land uplift for the area, the current rates from geodetic observations, and probabilistic scenarios for future relative sea level rise. The maximum land uplift rates in Fennoscandia are in the Bothnian Bay of the Baltic Sea, where the maximum values are currently on the order of $10 \mathrm{~mm} /$ year with respect to the geoid. During the last 100 years, the land has risen from the sea by approximately $80 \mathrm{~cm}$ in this area. Estimates of future relative sea level change have considerable uncertainty, with values for the year 2100 ranging from $75 \mathrm{~cm}$ of sea level fall (land emergence) to $30 \mathrm{~cm}$ of sea-level rise.
\end{abstract}

\section{Keywords}

Baltic Sea $\cdot$ Geodetic time series $\cdot$ Land uplift $\cdot$ Sea level rise

\section{Introduction}

Fennoscandia is a geodynamically active region due to the relatively recent (20-10 thousand years before present) demise of the large ice sheets that covered this region at the last glacial maximum. The weight of the ice sheets pressed the Earth's crust down and now, in the process called post glacial rebound, the crust is slowly uplifting as the Earth relaxes to a state of isostatic equilibrium. Fennoscandia has the highest number of land uplift related observations in the world (e.g. Poutanen and Steffen 2014), and the phenomenon

M. Nordman $\cdot$ A. Peltola $\cdot$ M. Bilker-Koivula $\cdot$ S. Lahtinen National Land Survey of Finland, Finnish Geospatial Research Institute, Kirkkonummi, Finland

M. Nordman ( $\square)$

Aalto University, School of Engineering, Espoo, Finland

e-mail: maaria.nordman@aalto.fi has also been studied for centuries (see e.g. Ekman 1999, 2009; Steffen and Wu 2011).

One sign of the uniqueness of the Fennoscandian uplift is the World Heritage Site status the Kvarken Archipelago (Finland) and High Coast (Sweden) have obtained (Fig. 1). As part of the Lystra project, funded by EU Interreg BotniaAtlantica program, which main aim is to update the knowledge and information materials for visitors of the World Heritage Site, we have been looking at the geodetic data available for the area to understand the land uplift patterns and magnitudes better (Peltola 2019) and to compare them to sea level rise scenarios to understand how the coastline might move in the future (Huuskonen 2020).

One active operator in geodesy in the Nordic area is the Nordic Geodetic Commission (NKG). The NKG was established 1953 to enhance the co-operation between geodesists in the Nordic countries (Denmark, Finland, Iceland, Norway and Sweden), nowadays also Baltic countries (Estonia, Latvia and Lithuania) are active. There are three NKG activi- 


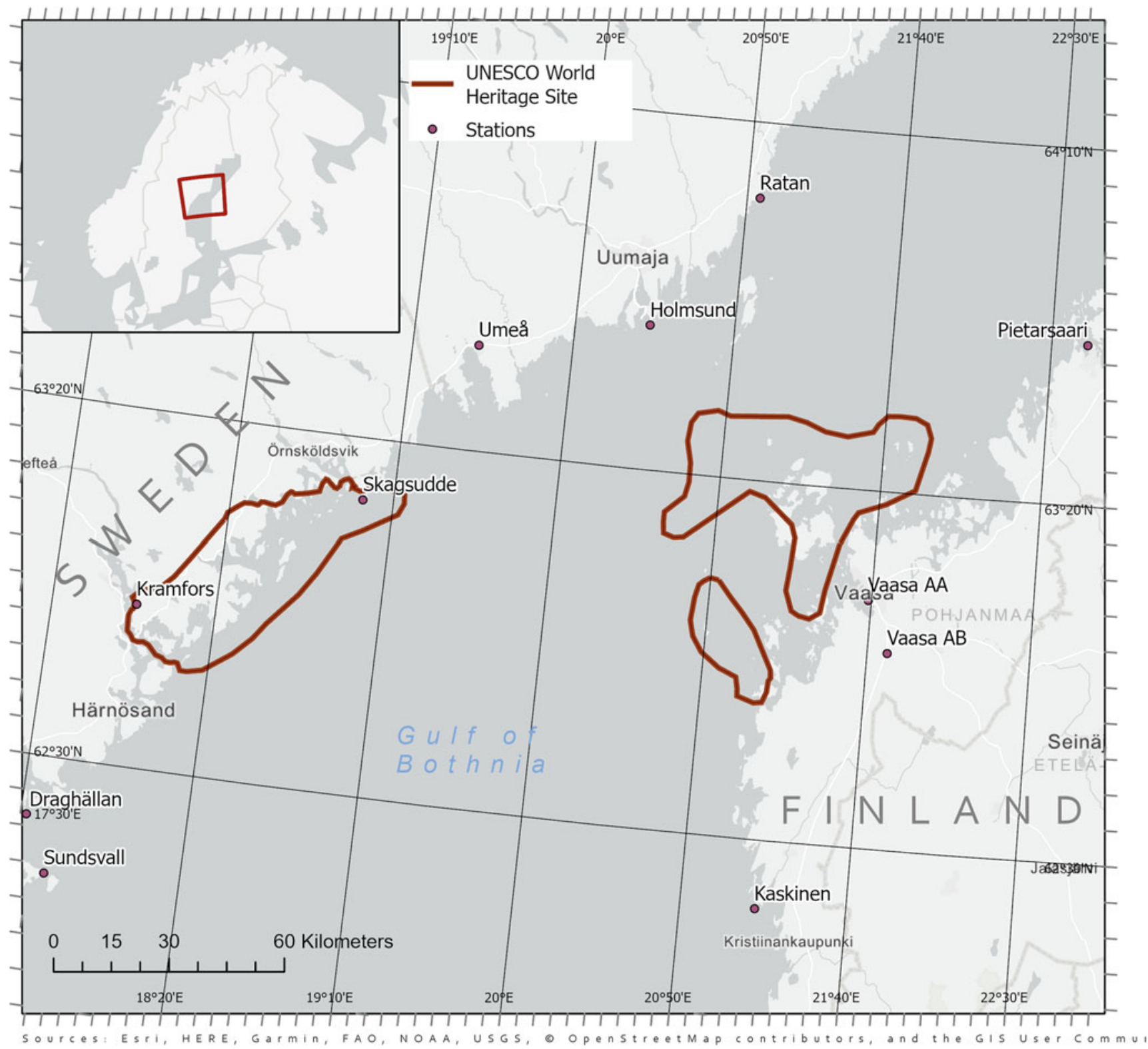

Fig. 1 The UNESCO World Heritage Site of Kvarken and High Coast in Northern Europe together with the geodetic observation points of the area

ties that are of interest for our study. Firstly, the NKG2016LU land uplift model (Vestøl et al. 2019) that was computed in co-operation in the Working Groups for Geodynamics and for Geoid and Height Systems. Secondly, the absolute gravity measurements that are discussed and published in co-operation in the Working Group of Geodynamics (e.g. Olsson et al. 2019). And thirdly, the NKG Analysis Centres, under the Working Group for the Reference Frames, which continuously process the GNSS data from the permanent GNSS stations (Lahtinen et al. 2018).

In this study we show comparisons of land uplift rates from selected geodetic techniques as well as probabilistic future scenarios for the Kvarken and High Coast areas. The second chapter describes the data and methods chosen, the third chapter shows and discusses the results. The last chapter is left for conclusions.

\section{Data and Methods}

\subsection{Geodetic Data}

The GNSS uplift values used in the present study were the trends from the NKG Analysis Centre solution by Lahtinen et al. (2019). There were altogether eight stations in the study area, one in Finland and seven in Sweden. The longest 
time series were approximately 20 years in length (Vaasa, Umeå and Sundsvall). The other stations have approximately 10 years of time series. The uncertainties in the time series are less than $0.1 \mathrm{~mm} /$ year. GNSS gives absolute uplift rates in a global reference frame. These rates must be converted to uplift rates relative to the geoid, as measured by repeated levelling, to be able to compare them to the sea level height changes. We do this using the differences between the absolute and relative versions of the NKG2016LU land uplift model (NKG2016LU_abs and NKG2016LU_lev, see below). The difference is in the order of $0.6 \mathrm{~mm} /$ year for our study area. The elastic deformation from present day glacier melt has an effect on the land uplift rates in Fennoscandia (Simon et al. 2018). For now, the effect is not included as the signal needs to be adequately approximated. In future studies the effect should be considered.

The absolute gravity (AG) observations were obtained from the NKG gravity database, published in Olsson et al. (2019), with some additions for the last years (2016-2018, pers. comm. P. Olsson, pers. comm. M. Bilker-Koivula). The gravity data gives information on the land uplift independent from the other observables or models. There are altogether five absolute gravity stations in the area with long time spans between 8 (Kramfors) and 20 years (Skellefteå, Vaasa AA and $\mathrm{AB}$ ). Here we use only data measured with the FG5type instruments (Niebauer et al. 1995). At Skellefteå and the Vaasa stations also measurements exist made with the JILAg-5 instrument (Faller et al. 1983). However, there is a suspicion that the JILAg-5 measurements may have an offset with respect to the FG5 measurements, as such an offset has been found for other JILAg instruments (Timmen et al. 2008; Lambert et al. 2001; Pálinkáš et al. 2013). Also, Olsson et al. (2019) suggest that the JILAg-5 may have an offset and leave JILAg data out of the final solution. To avoid offset problems, we use only FG5 data in this study. The FG5 data have uncertainties of 2-3 $\mu \mathrm{Gals}$ (where $1 \mu \mathrm{Gal}$ is $10^{-8} \mathrm{~m} / \mathrm{s}^{2}$ ).

Absolute gravity measurements are subject to changes in the environment such as variations in local hydrology. If information on the hydrological signal is available this can be used to reduce the variation of the gravity time series (see e.g. Ophaug et al. (2016), Lambert et al. (2006) and Mikolaj et al. (2015)). Modelling of the hydrological signal is however out of the scope of this paper and we assume that our long time series will cancel out any seasonal variations in gravity.

To obtain the land uplift from the gravity change values, a ratio of $-0.163 \mu \mathrm{Gal} / \mathrm{mm}$ was used (Olsson et al. 2015) with the uncertainty $\pm 0.016 \mu \mathrm{Gal} / \mathrm{mm}$ (Ophaug et al. 2016). The ratio is theoretically predicted for a visco-elastic Earth model and confirmed by absolute gravity observations (Olsson et al. 2019). Like the GNSS uplift rates, the gravity derived uplift rates are absolute, as the absolute gravity observations give the rate of change with respect to the center of mass. Thus, correction for geoid rise needs to be added.

The land uplift model that was used for the comparison is the semi-empirical NKG2016LU model (Vestøl et al. 2019). The model combines GNSS time series and levelling as observations with a GIA (glacial isostatic adjustment) model covering the areas where observations are sparse (e.g. on the sea). The model's uplift rates are available relative to ellipsoid (NKG2016LU_abs) or to geoid (NKG2016LU_lev). We chose the latter. The model comes with uncertainty values that are in general slightly less than $0.2 \mathrm{~mm} /$ year.

\subsection{Sea Level Data}

The sea level data was obtained from the PSMSL data base (Holgate et al. 2013). The data consist of yearly mean averages for all tide gauge stations near the study area. There are three tide gauges on the Finnish side and two on the Swedish side. The time periods for the stations vary somewhat, the earliest observations start in the early twentieth century and all, except one station, are still running. The problem with the tide gauges is that the eustatic sea level change, meaning the global sea level change because of mass and volume changes of the oceans, has changed over the years (e.g. Johansson et al. 2004; Dangendorf et al. 2019), thus using a single number for long time series would produce optimistic numbers for the land uplift rates. In the Baltic Sea the trend in tide gauge record has been estimated to be stable up to 1980, after which it has started to change (Johansson et al. 2003, 2014). We, therefore, decided to use time series only up to 1980 for the land uplift estimates, to diminish the effect of the changing global sea level. A uniform time period was chosen for all the stations after some research. In order to compare the tide gauge trends to geodetic trends, the eustatic sea level rise of $1.0 \mathrm{~mm} / \mathrm{year}$ for twentieth century (Ekman and Mäkinen 1996) was removed.

\subsection{Future Scenarios}

In order to study how the World Heritage Site will change in the future, we compared our results of what has happened in the last 100 years to probabilistic future scenarios computed into 2100 by Pellikka et al. (2018). We took the 5\%,50\% and $95 \%$ probability values for our comparison. The $50 \%$ is the median value expected at each site by 2100 and the $5 \%$ and $95 \%$ are low- and high-end scenarios. The three components affecting the sea level rise in the Baltic Sea are the land uplift, the global mean sea level rise and the meteorological component, i.e. the effect of westerly winds that might increase in the future. The scenarios in Pellikka et al. (2018) take into account these components on the Finnish 
coast. As we have stations also on the Swedish coast, we have paired the Swedish stations with Finnish stations that are located on approximately the same latitude from Pellikka et al. (2018), based on the assumption that the whole gulf would react similarly to future changes. To estimate the future scenarios we take the sea level scenario value from Table 3 in Pellikka et al. (2018), remove the land uplift they have used (listed in the same table) and add back the land uplift rate from our observations.

\section{Results and Discussion}

All the land uplift rates from different techniques are listed in Table 1. The uplift rates from geodetic data, i.e. GNSS and absolute gravity are shown in the first five columns of Table 1. All the trends are converted to trends relative to the geoid for comparison. In the sixth and seventh column are the changing sea levels $(\dot{S})$, which have a negative sign, as the sea level falls relative to ground. Different time periods give somewhat different results for the tide gauges. We tested different time periods for each tide gauge (not shown here), depending on when the tide gauges started operating, if there were data gaps or other issues. We concluded that the period up to 1979 shows the land uplift best and took, when possible, the same time period for all stations. The $\dot{H}_{w \text {.mean }}$ in the second last column was computed by weighing the observations by their variance, if there were more than one technique available, meaning that the GNSS time series with their small standard deviations give the biggest impact to the weighted mean and its standard deviation. The last column shows the rates from the NKG2016LU model for comparison.

\subsection{Geodetic and Sea Level Data}

As can be seen from Table 1, the GNSS and AG results agree quite well, especially within uncertainty. The Vaasa station has previously shown some anomalistic low GNSS-derived rates (Kierulf et al. 2014; Lidberg et al. 2009), which has now been addressed to changing surroundings of the station. For the Lahtinen et al. (2019) result the time series has been modified more drastically and fits now the overall picture better. The absolute gravity value of Vaasa AA is somewhat higher than expected. We suspect that this is due to changes in local hydrology over the years near the station. However, this is speculation and must be subject of further studies. The NKG2016LU values agree better with GNSS, which is not surprising as the model has GNSS values inside it.

The tide gauges have comparable values to geodetic measurements, in the order of 7-9 $\mathrm{mm}$ per year sea level fall. When comparing to previous studies (e.g. Ekman 1996; Pellikka et al. 2018) our values are in the same range.

\subsection{Comparison of Geodetic and Sea Level Trends}

The land uplift rates from different techniques show comparable results, as could be expected. The maximum rates are on the Swedish side, whereas the Finnish sites have slightly lower values. The absolute gravity shows somewhat higher values, which might relate to mass changes that are not induced by land uplift or that the ratio derived using visco-elastic Earth model is not optimal for the maximum uplift area. However, the underestimation of gravity rates estimated by Olsson et al. (2015) for the areas close to
Table 1 The land uplift rates from different techniques. $\dot{h}_{G P S}$ and $\dot{H}_{G N S S}$ are the absolute and relative vertical rates of the permanent GNSS stations. $\dot{g}_{A G}$ are the absolute gravity change rates from AG data and $\dot{h}_{A G}$ and $\dot{H}_{A G}$ are the absolute and relative vertical rates derived from the absolute gravity data. $\dot{S}_{1920-1979}$ are the sea level change for years $1920-1979$ and for comparison we show also $\dot{S}_{1919-2018}$, change within the last 100 years (to be used in Table 2). $\dot{H}_{T G}$ are the relative land uplift rates from tide gauges. The bold numbers were used to compute the weighted mean $\dot{H}_{\text {w.mean }} . \dot{H}_{N K G}$ are the vertical rates from the NKG2016LU_lev land uplift model

\begin{tabular}{|c|c|c|c|c|c|c|c|c|c|c|}
\hline & $\dot{h}_{G N S}$ & $\dot{H}_{G N S S}$ & $\dot{g}_{A G}$ & $\dot{h}_{A G}$ & $\dot{H}_{A G}$ & $\dot{S}_{1920-79}$ & $\dot{S}_{1919-2018}$ & $\dot{H}_{T G}$ & $\dot{H}_{\text {w.mean }}$ & $\dot{H}_{N K G}$ \\
\hline Station & $\mathrm{mm} / \mathrm{a}$ & $\mathrm{mm} / \mathrm{a}$ & $\mu \mathrm{gal} / \mathrm{a}$ & $\mathrm{mm} / \mathrm{a}$ & $\mathrm{mm} / \mathrm{a}$ & $\mathrm{mm} / \mathrm{a}$ & $\mathrm{mm} / \mathrm{a}$ & $\mathrm{mm} / \mathrm{a}$ & $\mathrm{mm} / \mathrm{a}$ & $\mathrm{mm} / \mathrm{a}$ \\
\hline Pietarsaari & & & & & & $-8.5 \pm 0.5$ & $-7.1 \pm 0.3$ & $9.5 \pm 0.7$ & $9.5 \pm 0.69$ & $9.0 \pm 0.2$ \\
\hline Vaasa AA & & & $-1.8 \pm 0.2$ & $10.8 \pm 1.4$ & $10.2 \pm 1.4$ & $-7.9 \pm 0.5$ & $-7.0 \pm 0.2$ & $8.9 \pm 0.7$ & $9.2 \pm 0.59$ & $8.8 \pm 0.2$ \\
\hline Vaasa AB & $9.1 \pm 0.06$ & $8.5 \pm 0.06$ & $-1.6 \pm 0.1$ & $9.8 \pm 1.3$ & $9.2 \pm 1.3$ & & & & $8.5 \pm 0.06$ & $8.6 \pm 0.2$ \\
\hline Kaskinen $^{\mathrm{a}}$ & & & & & & $-7.3 \pm 0.7$ & $-6.3 \pm 0.3$ & $8.3 \pm 0.7$ & $8.3 \pm 0.67$ & $8.3 \pm 0.2$ \\
\hline Skellefteå ${ }^{\circ}$ & $10.3 \pm 0.08$ & $9.6 \pm 0.08$ & $-1.8 \pm 0.1$ & $11.0 \pm 1.2$ & $10.4 \pm 1.2$ & $-9.5 \pm 0.5$ & $-7.9 \pm 0.3$ & $10.5 \pm 0.7$ & $9.6 \pm 0.08$ & $9.5 \pm 0.2$ \\
\hline Bjuröklubb & $10.0 \pm 0.05$ & $9.4 \pm 0.05$ & & & & & & & $9.4 \pm 0.05$ & $9.5 \pm 0.2$ \\
\hline Ratan & $10.1 \pm 0.10$ & $9.4 \pm 0.10$ & $-1.7 \pm 0.3$ & $10.7 \pm 2.3$ & $10.0 \pm 2.3$ & $-8.5 \pm 0.5$ & $-7.7 \pm 0.3$ & $9.5 \pm 0.7$ & $9.4 \pm 0.10$ & $9.5 \pm 0.2$ \\
\hline Holmsund & $10.0 \pm 0.08$ & $9.4 \pm 0.08$ & & & & & & & $9.4 \pm 0.08$ & $9.5 \pm 0.2$ \\
\hline Umeå & $10.3 \pm 0.01$ & $9.6 \pm 0.01$ & & & & & & & $9.6 \pm 0.01$ & $9.6 \pm 0.1$ \\
\hline Kramfors & $10.0 \pm 0.06$ & $9.4 \pm 0.06$ & $-1.7 \pm 0.3$ & $10.2 \pm 2.0$ & $9.5 \pm 2.0$ & & & & $9.4 \pm 0.06$ & $9.2 \pm 0.2$ \\
\hline Sundsvall & $9.5 \pm 0.04$ & $8.9 \pm 0.04$ & & & & & & & $8.9 \pm 0.04$ & $8.9 \pm 0.2$ \\
\hline
\end{tabular}

${ }^{a}$ Kaskinen observations start in 1926

${ }^{\mathrm{b}}$ Skellefteå (GPS and AG) was combined with Furuögrund tide gauge 
the maximum uplift, are around $0.02 \mu \mathrm{Gal} / \mathrm{year}$, which is of an order smaller than the deviations we see between the absolute gravity rates and the gravity changes derived from the NKG2016LU_gdot model (Olsson et al. 2019). The GNSS dominated weighted mean values have clearly lower uncertainty than the land uplift model, whereas the other techniques' uncertainties are two of threefold. The uncertainty of GNSS time series has been studied a lot and it has been suggested that the true uncertainty might be in the order of $0.2-0.3 \mathrm{~mm} /$ year (Lahtinen et al. 2019). This requires still more investigation.

Also the elastic component of the present day melting studied by Simon et al. (2018) could affect both the measurements and modelling. They did not use terrestrial gravity measurements so the effect to this type of study would require more studies.

\subsection{Future}

The future scenarios from Pellikka et al. (2018) modified using our uplift rates are shown in Table 2. To show the effect on coastline, Fig. 2 shows the future scenarios for the Björkö island in Kvarken as an example, The topography is much steeper on the High Coast side and does not really show much change even with the higher sea level rise scenarios (Huuskonen 2020). The relative sea level fall could not be visualized, because we have no bathymetry data with adequate resolution available for the area.

The future of the Kvarken and High Coast in the coming 100 years remains uncertain as the future scenarios are uncertain. It looks very likely that the land uplift will compensate for the globally rising sea levels, although, depending on the rate of the future sea level rise, land subsidence is possible even in the maximum land uplift area. The sea level change will affect the coast line on the east and west coast of the Bothnian Bay differently, due to different topography of the landscape. The Hight Coast has very steep topography, which will not be affected much by the rising sea level. In Kvarken the situation is quite the opposite and the landscape is very flat and prone to flooding. Rising sea levels can easily drown landmarks and call for adjustments e.g. in infrastructure. We are taking a closer look at this topic on another publication that is under preparation (Huuskonen and Nordman in prep).

\section{Conclusions}

We have studied the land uplift in the Bothnian Bay of the Baltic Sea. We have computed the current rates of uplift from geodetic observations, and probabilistic scenarios for future relative sea level rise in the area. The maximum land uplift rates in Fennoscandia are in the Bothnian Bay, where the maximum values are currently on the order of $10 \mathrm{~mm} / \mathrm{year}$ with respect to the geoid. During the last 100 years, the land has risen from the sea by up to $80 \mathrm{~cm}$ in this area. Estimates of future relative sea-level change have considerable uncertainty, with values for the year 2100 ranging from $75 \mathrm{~cm}$ of sea-level fall (land emergence) to $30 \mathrm{~cm}$ of sea-level rise.

The different techniques we have used give similar results, as could be expected. There are some discrepancies, most likely due to different time periods used for different techniques as well as effects of other phenomena, e.g. changes in local hydrology. Combining the techniques produces some challenges, as all techniques studied here measure different part of the land uplift phenomenon. This can also be seen as an advantage and can be used to distinguish between different parts, namely uplift, mass changes and their relation. Some issues in the differences can be addressed to the theoretical and empirical relations between the measurement types.

The most uncertain part in the current study is the future. The future scenarios cover a wide range, and the uncertainty

Table 2 The probabilistic future scenarios of relative sea level rise for stations in our study area, showing the relative land uplift for the past 100 years from tide gauge time series (first column, see also Table 1)

for the tide gauge stations, and change to year 2100 for $5 \%, 50 \%$ and $95 \%$ probabilities. The unit is $\mathrm{cm}$

\begin{tabular}{l|l|l|l|l}
\hline Station & $1919-2018(\mathrm{~cm})$ & $2000-99: 5 \%$ & $2000-99: 50 \%$ & $2000-99: 95 \%$ \\
\hline Pietarsaari & $71 \pm 2.6$ & -25 & 27 & 70 \\
\hline Vaasa AA & $70 \pm 2.3$ & -27 & 25 & 68 \\
\hline Vaasa AB & $70 \pm 2.3$ & -35 & 17 & 60 \\
\hline Kaskinen & $63 \pm 2.8$ & -44 & 11 & 55 \\
\hline Skellefteå/Furuögrund & $79 \pm 2.6$ & -24 & 28 & 71 \\
\hline Bjuröklubb & & -27 & 25 & 68 \\
\hline Ratan & $77 \pm 2.5$ & -26 & 26 & 69 \\
\hline Holmsund & & -27 & 25 & 68 \\
\hline Umeå & & -23 & 29 & 72 \\
\hline Kramfors & -25 & 27 & 70 \\
\hline Sundsvall & & -37 & 18 & 62 \\
\hline
\end{tabular}




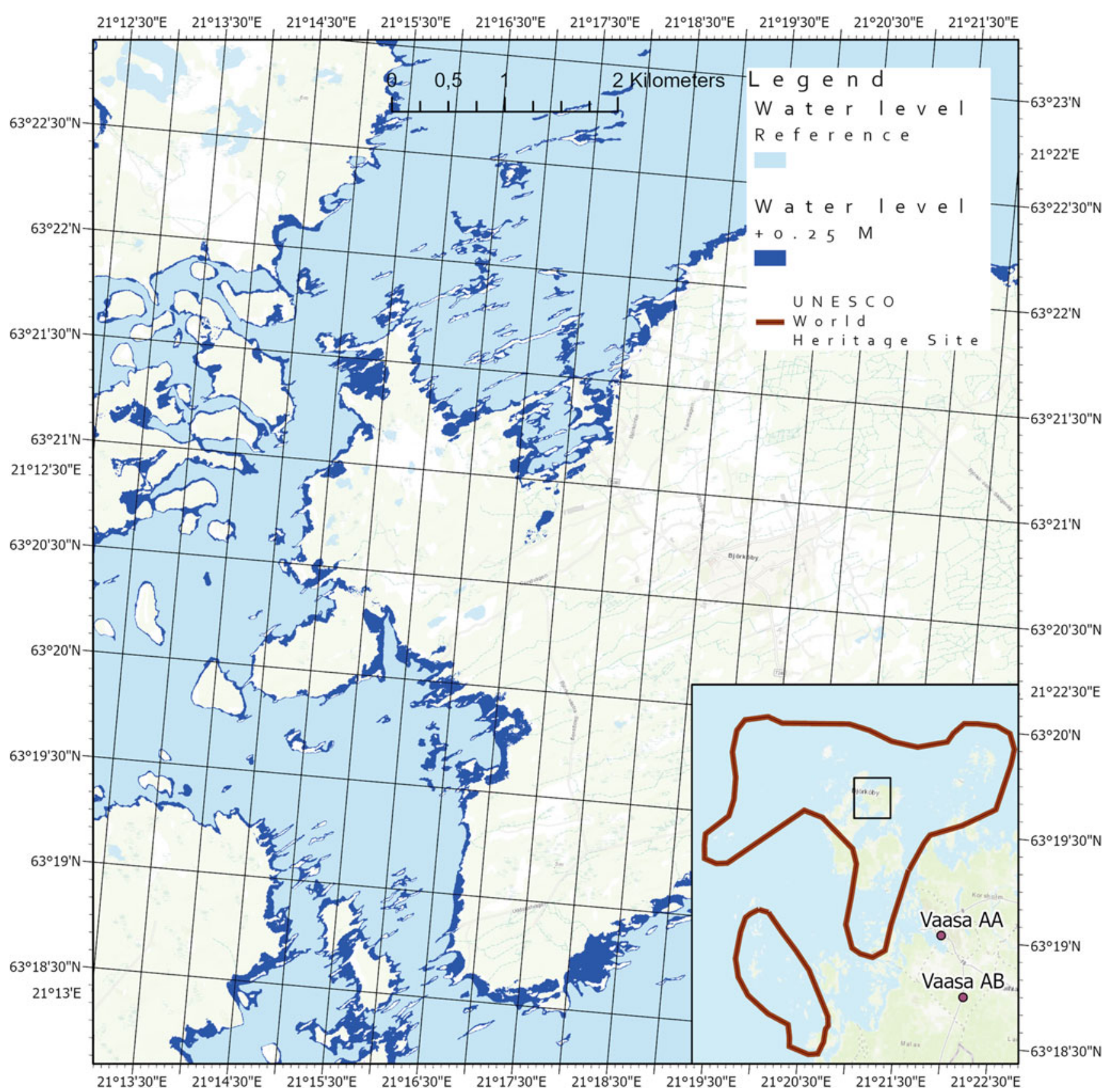

Fig. 2 The future scenario of Table 2 plotted for Kvarken's Björkö. The light blue shows the present coast line, and the dark blue the 95\% probability scenario (sea level rise of $25 \mathrm{~cm}$ )

of the projections into year 2100 is large, even if it is fitted to local conditions as in Pellikka et al. (2018). Also the effect of the changing coast line is uncertain and should be studied further.

Acknowledgements Aleksi Peltola was funded by European Union Interreg Botnia-Atlantica project Lystra. Maaria Nordman was funded by the Academy of Finland (project number 299626). Erja Huuskonen is kindly acknowledged for Figs. 1 and 2.

\section{References}

Dangendorf S, Hay C, Calafat FM, Marcos M, Piecuch CG, Berk K, Jensen J (2019) Persistent acceleration in global sea-level rise since the 1960s. Nat Clim Chang 9(9):705-710

Ekman M (1996) A consistent map of the postglacial uplift of Fennoscandia. Terra Nova 8(2):158-165

Ekman M (1999) Climate changes detected through the world's longest sea level series. Glob Planet Chang 21(4):215-224. https://doi.org/ 10.1016/S0921-8181(99)00045-4 
Ekman M (2009) The changing level of the Baltic Sea during 300 years: a clue to understanding the earth. The Summer Institute for Historical Geophysics, Åland Islands, pp 1-155. ISBN 978-952-92-5241-1

Ekman M, Mäkinen J (1996) Recent postglacial rebound, gravity change and mantle flow in Fennoscandia. Geophys J Int 126(1):229 234. https://doi.org/10.1111/j.1365-246X.1996.tb05281.x

Faller JE, Guo YG, Gschwind J, Niebauer TM, Rinker RL, Xue J (1983) The JILA portable absolute gravity apparatus. BGI Bull Inf 53:87-97

Holgate SJ, Matthews A, Woodworth PL, Rickards LJ, Tamisiea ME, Bradshaw E, Foden PR, Gordon KM, Jevrejeva S, Pugh J (2013) New data systems and products at the permanent service for mean sea level. J Coast Res 29(3):493-504. https://doi.org/10.2112/ JCOASTRES-D-12-00175.1

Huuskonen E (2020) Sea-level rise and land uplift in Kvarken and high coast area in 2300. Aalto University, Espoo

Huuskonen E, Nordman M (in prep) Relative sea level rise in the Kvarken archipelago and the High Coast in 2300

Johansson MM, Kahma KK, Boman H (2003) An improved estimate for the long-term mean sea level on the Finnish coast. Geophysica 39(1-2):51-73

Johansson MM, Kahma KK, Boman H, Launiainen J (2004) Scenarios for sea level on the Finnish coast. Boreal Environ Res 9:153-166. ISSN: 1239-6095

Johansson MM, Pellikka H, Kahma KK, Ruosteenoja K (2014) Global Sea level rise scenarios adapted to the Finnish coast. J Mar Syst 129:35-46. https://doi.org/10.1016/j.jmarsys.2012.08.007

Kierulf HP, Steffen H, Simpson MJR, Lidberg M, Wu P, Wang H (2014) A GPS velocity field for Fennoscandia and a consistent comparison to glacial isostatic adjustment models. J Geophys Res Solid Earth 119(8):6613-6629. https://doi.org/10.1002/2013JB010889

Lahtinen S, Häkli P, Jivall L, Kempe C, Kollo K, Kosenko K, Pihlak $\mathrm{P}$, Prizginiene D, Tangen O, Weber M, Paršeliunas E, Baniulis R, Galinauskas K (2018) First results of the Nordic and Baltic GNSS analysis Centre. J Geodetic Sci 8:34-42. https://doi.org/10.1515/ jogs-2018-0005

Lahtinen S, Jivall L, Häkli P, Kall T, Kollo K, Kosenko K, Galinauskas K, Prizginiene D, Tangen O, Weber M, Nordman M (2019) Densification of the ITRF2014 position and velocity solution in the Nordic and Baltic countries. GPS Solutions 23(4):95. https://doi.org/ 10.1007/s10291-019-0886-3

Lambert A, Courtier N, Sasagawa GS, Klopping F, Winester D, James TS, Liard JO (2001) New constraints on Laurentide postglacial rebound from absolute gravity measurements. Geophys Res Lett 28(10):2109-2112

Lambert A, Courtier N, James TS (2006) Long-term monitoring by absolute gravimetry: tides to postglacial rebound. J Geodyn 41:307317. https://doi.org/10.1016/j.jog.2005.08.032

Lidberg M, Johansson JM, Scherneck HG, Milne GA (2009) Recent results based on continuous GPS observations of the GIA process in Fennoscandia from BIFROST. J Geodyn 50(2010):8-18. https://doi. org/10.1016/j.jog.2009.11.010
Mikolaj M, Meurers B, Mojzeš M (2015) The reduction of hydrologyinduced gravity variations at sites with insufficient hydrological instrumentation. Stud Geophys Geod 59:1-xxx. https://doi.org/10. 1007/s11200-014-0232-8

Niebauer TM, Sasagawa GS, Faller JE, Hilt R, Klopping F (1995) A new generation of absolute gravimeters. Metrologia 32:159-180

Olsson P-A, Milne G, Scherneck H-G, Ågren J (2015) The relation between gravity rate of change and vertical displacement in previously glaciated areas. J Geodyn 83:76-84. https://doi.org/10.1016/j. jog.2014.09.011

Olsson P-A, Breili K, Ophaug V, Steffen H, Bilker-Koivula M, Nielsen E, Oja T, Timmen L (2019) Postglacial gravity change in Fennoscandia - three decades of repeated absolute gravity observations. Geophys J Int 217:1141-1156. https://doi.org/10.1093/gji/ggz054

Ophaug V, Breili K, Gerlach C, Gjevestad JGO, Lysaker DI, Omang OCD, Pettersen BR (2016) Absolute gravity observations in Norway (1993-2014) for glacial isostatic adjustment studies: the influence of gravitational loading effects on secular gravity trends. J Geodyn 102:83-94

Pálinkáš V, Lederer M, Kostelecký J, Šimek J, Mojzeš M, Ferianc D, Csapó G (2013) Analysis of the repeated absolute gravity measurements in the Czech Republic, Slovakia and Hungary from the period 1991-2010 considering instrumental and hydrological effects. J Geod 87:29-42. https://doi.org/10.1007/s00190-012-0576-1

Pellikka H, Leijala U, Johansson MM, Leinonen K, Kahma KK (2018) Future probabilities of coastal floods in Finland. Cont Shelf Res 157:32-42. https://doi.org/10.1016/j.csr.2018.02.006

Peltola A (2019) Korkearannikon ja Merenkurkun saariston maailmanperintökohteen maanpinnan kohoamisnopeuden havaitseminen eri menetelmillä. (The land uplift rate at the world heritage site high coast and Kvarken archipelago observed with different methods). Aalto University, Espoo. (in Finnish)

Poutanen M, Steffen H (2014) Land uplift at Kvarken Archipelago/High Coast UNESCO world heritage area. Geophysica 50(2):49-64

Simon KM, Riva RE, Kleinherenbrink M, Frederikse T (2018) The glacial isostatic adjustment signal at present day in northern Europe and the British Isles estimated from geodetic observations and geophysical models. Solid Earth 9(3):777

Steffen H, Wu P (2011) Glacial isostatic adjustment in Fennoscandia a review of data and modeling. J Geodyn 52(3-4):169-204

Timmen L, Gitlein O, Müller J, Strykowski G, Forsberg R (2008) Absolute gravimetry with the Hannover meters JILAg-3 and FG5220, and their deployment in a Danish-German cooperation. ZFV - Zeitschrift fur Geodasie, Geoinformation und Landmanagement 133(3):149-163

Vestøl O, Ågren J, Steffen H, Kierulf H, Tarasov L (2019) NKG2016LU: a new land uplift model for Fennoscandia and the Baltic region. J Geod 93(9):1759-1779, 1-21

Open Access This chapter is licensed under the terms of the Creative Commons Attribution 4.0 International Licence (http://creativecommons. org/licenses/by/4.0/), which permits use, sharing, adaptation, distribution and reproduction in any medium or format, as long as you give appropriate credit to the original author(s) and the source, provide a link to the Creative Commons licence and indicate if changes were made.

The images or other third party material in this chapter are included in the chapter's Creative Commons licence, unless indicated otherwise in a credit line to the material. If material is not included in the chapter's Creative Commons licence and your intended use is not permitted by statutory regulation or exceeds the permitted use, you will need to obtain permission directly from the copyright holder.

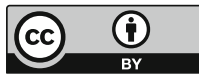

